\title{
Understanding the Behavioral Paradox of the Companies' by Using "The Corporation" Documentary
}

\author{
Aysegul Ozbebek Tunc ${ }^{1}$, Esra Kilicarslan Toplu ${ }^{2} \&$ Selim Yazici ${ }^{1}$ \\ ${ }^{1}$ Faculty of Political Sciences, Istanbul University, Istanbul, Turkey \\ ${ }^{2}$ Istanbul University, Istanbul, Turkey \\ Correspondence: Aysegul Ozbebek Tunc, Faculty of Political Sciences, Istanbul University, Istanbul, Turkey.
}

Received: February 23, 2017

Accepted: April 19, 2017

Online Published: April 24, 2017

doi:10.5539/ibr.v10n5p169

URL: https://doi.org/10.5539/ibr.v10n5p169

\begin{abstract}
Films are widely used in business education to illuminate management concepts. Since films can provide a version of how theories and concepts can actually be put into practice, they have more lasting impression. On the other hand; ethical issue are complicated and they involve many processes and influences that are diverse and interlinked. That's why it is difficult for students to understand potential conflicts of interest if they lack business experience or frame of reference. In this study, "The Corporation", a documentary film by March Achbar, Jennifer Abbott and Joel Bakan, which has received awards in film festivals around the world, has been used for analysis to illustrate the behavioral paradox of corporations. Film analysis has been used as an educational tool in order to teach organizational behavior and management concepts since 1970s. To check our assumption we have designed a study to explore whether using "The Corporation" documentary in classroom settings will raise the awareness of the students about the role that corporations play in ethical, social, and environmental issues which are essential for business decisions, and thus enable the students -the future business managers-, to understand the paradoxical behaviors of corporations. After the students watched "The Corporation", a quantitative analysis has been conducted by comparing the written essays of the students as regards their interpretation of the film.
\end{abstract}

Keywords: business ethics, ethical decision-making, business ethics education, corporate social responsibility, film analysis

\section{Introduction}

Films are said to be a powerful tool for teaching students. With the ability to shift perspectives and conceptual flexibility (Champoux, 1999), they can be used as a case study, to solve problems, to give importance to abstract concepts, to provide vicarious experience and to illustrate historical events. It is also a powerful tool for demonstrating the application of the theory and illustrating the concepts in order to provide students with meaningful opportunities to observe and to understand stakeholder interactions (Champoux, 1999; Buchanan \& Huczynski, 2004). Selected film scenes from feature films can also offer exceptional visual and dramatic presentations of various aspects of business ethics and moral reasoning (Champoux, 2006). In addition; we are living in a culture dominated by electronic media, demographic structure of classes are changing and instructors are expected to be sensitive to "digital native" learners' needs (Fee and Budde-Sung, 2014).

Documentary films are said to be one of the potential tool to influence people's behaviors (Janpol and Dilts, 2016). The documentary, "The Corporation" can be used as a valuable teaching tool, because for business students, it provides a context and imagery, in which they experience the fundamental conflicts arising as a result of corporate actions. Business students need to have the awareness that they will probably face some ethical or environmental problems while making business decisions. Real illustrations of ethical dilemmas faced by corporations on their day-to-day interactions and transactions, discussed by business people involved in the problems, is a very effective method for business students to face some of these issues and make their own judgments.

In this study, "The Corporation" (Abbott \& Achbar, 2005), a documentary film by March Achbar, Jennifer Abbott and Joel Bakan, which has received many awards in film festivals around the world, has been used to illustrate the behavioral paradox of corporations as a result of ethical dilemmas that arise in everyday business. 
The film starts with the premise that a legal person's rights have been given to the corporations, so corporations must be evaluated as a person and one must think about what kind of person the corporation is. As one of the indispensable actors of the society, positions and responsibilities of corporations in the society are examined with a critical perspective in the film.

When teaching business concepts; it is a challenge to link the wide variety of theories to the "real world" and provide students with an organizational frame of reference to help them understand and appreciate the relevance and context within the subject. (Kester, Cooper, Dean, Gianiodis and Goldsby, 2009). It is pointed out that; concepts that are difficult-to-teach can be shown and taught by films (Higgins \& Dermer, 2001). Since ethical problems are complicated, interrelated, and mostly there are more than one right answer, the use of films like "The Corporation" documentary, helps students to understand the ethical issues business people face during their everyday life.

In this study, we hypothesize that using of the documentary "The Corporation" in a Business Ethics and Corporate Social Responsibility course will create a relatively higher level of understanding on students watching the film, than that of the other group, for ethical dilemmas caused by behavioral paradox of corporations.

The study is structured by parts of introduction, method, results and discussion. Introduction section includes identification of research problem and discusses theoretical background including teaching with films, behavioral paradox managers face, and ethical decision making. Data and study design are described and examined in method and results sections. Final section offers remarkable notes, discussion, implications for managers and future research suggestions.

\subsection{Theoretical Background}

\subsubsection{Teaching with Films}

In the early twentieth century, very soon after the motion pictures appeared as a medium for entertainment, many educators began to dig out the films in order to use them as a learning aid in the classroom (Huczynski \& Buchanan, 2006). Butler, Zaromb, Lyle and Roediger (2009) states that in 1918, Sumstine (1918) conducted a study of visual education in high school, and in 1933, Hansen (1933) tried to determine the contribution of educational films to the retention of informational learning. Ohio State University professor W.J. Fleig (1950) affirms that: "movies make it possible to bring to students types of industrial activities which are foreign to their locality. The films may be presented during regular class hours and can be tied in with a class discussion. All or part of a film may be repeated if desired" and the idea of using films in business education dates back to this statement.

Since the 1970s, educators have experienced using the film as a teaching tool and this tool's adoption by others have been encouraged and urged. Wegner was one of the first researchers to use this medium. In his 1977 booklet (Wegner, 1977), he described different kinds of films and showed the use of them in the classroom. Many other studies in social sciences (such as history, English, psychology, business, and etc.) have empirically showed that; films are effective tools to increase students' interest, understanding and engagement in the courses (Foreman \& Thatchenkery, 1996; Scherer \& Baker, 1999; Champoux, 1999; Comer, 2001; Huczynski \& Buchanan, 2004; Champoux, 2004; Buchanan \& Huczynski, 2004; Clawson, 2006; Frieden \& Deborah, 2007; Gonzales \& Zarzosa, 2008; Butler, et.al., 2009). Using films as an educational resource to illustrate business management concepts like ethical decision-making, risk taking, leadership, communication, strategic management and, organizational culture have also been discussed by many researchers (Scherer \& Baker, 1999; Champoux, 1999; Mallinger \& Rossy, 2003; Champoux, 2006; Ambrosini, Billsberry and Collier, 2008; Butler, et.al, 2009; Tyler, Anderson and Tyler, 2009; Smith, 2009).

In order to understand and grasp the relevance and context of the subject; most students require the organizational frame of reference needed (Kester, 2008). Films have a particular value when teaching inexperienced students whose knowledge is limited about business practices and workplace. Films provide students a different perspective about many topics that affect management theory and practice that they might not have experienced in person (Mallinger \& Rossy, 2003). Many educators theorize that films increase students' attention and learning. Champoux (1999) suggested using films because films offer a visual portrayal of theories and concepts taught in organizational behavior and business management courses. In addition, films can provide a common reference point for students to observe management practice (Ambrosini, et.al, 2008). Feature films can also be used to demonstrate the chaos, dynamic complexity and irregularity in organizational settings (Smith, 2009). Using films in class can be a valuable supplement to traditional textbooks that are used more to fragment and simplify for presentational purposes (Dunphy, Meyer and Linton, 2008). And because films mimic real-life 
experience more than case studies, students are affected more because what they see and hear influence them more than what they read (O'Boyle and Sandona, 2013). Films are also used for engaging and retaining the students because they are attention capturing (Scherer \& Baker, 1999). They also provide platforms for analyzing and integrating the topics, which are usually taught separately (Buchanan \& Huczynski, 2004).

It is vital that, for providing the opportunity to students to study the related subject, the selected film has the potential. Bumpus (2005) has used some criteria to determine whether a film will be an effective learning stimulus in the classroom: exemplification and clarification of applicable course concepts, engagement, awareness of interrelationships and interdependencies, previous use, running time, accessibility, stereotypical roles, subtitled foreign films and exposure to diverse stakeholders are some of the criteria that he has suggested. As a result, when choosing a film or a documentary to be used as a medium in classroom settings, it is important to consider these criteria to create an impact on students.

Table 1 represents a short list of films that have been used in management and business ethics courses as a teaching material, with their topics (or related business concepts), and the researchers who have examined them. This selection includes Enron to illustrate the business ethics (Cox, 2009); Rising Sun to teach cross cultural communication and to understand transplant organizations (Foreman \& Thatchenkery, 1996); 12 Angry Men to see biases, conflict and power issues, Thirteen Days to illustrate complex and politicized decision processes (Buchanan \& Huczynski, 2004); Dead Poets Society to stimulate class discussion on issues such as ethics, values, and organizational pressures toward conformity, and on role conflict and autonomy (Berger \& Pratt, 1998); A Soldier's Story to explore leadership and power analysis, The Associate to analyze new ventures, The Smoke Signals to assess communication and perception analysis, The Joy Luck Club to understand motivation and personality subjects (Bumpus, 2005); Gung Ho to explain cultural issues (Mallinger \& Rossy, 2003); The Breakfast Club (Christopher, Walter, Marek and Koenig, 2004) and Slumdog Millionaire (Cardon, 2010) to stimulate discussion of issues related to stereotyping and prejudgment; Crash to illustrate the significance of knowing other cultures and how this can influence communication between individuals (Villalba \& Redmond, 2008) and many films suggestions to teach strategic management (Ambrosini, et.al 2008).

Table 1. Examples of Films Used as a Teaching Material in Management and Business Ethics Education (Films and Relates Business Concepts)

\begin{tabular}{|c|c|c|}
\hline Film (alphabe tically) & Topic(s) & Researcher(s) \\
\hline 12 Angry Men (1957) & Biases, conflict and power issues & Buchanan and Huczynski (2004) \\
\hline A Soldier's Story (1984) & Leadership and power & Bumpus (2005) \\
\hline Casablanca (1942) & Ethics in a societal sense & Macy and Terry (2008) \\
\hline Crash (2004) & Culture and communication & Villalba and Redmond (2008) \\
\hline Dead Poet Society (1989) & $\begin{array}{l}\text { Ethics, values, and organizational } \\
\text { pressures toward conformity }\end{array}$ & Berger and Pratt (1998) \\
\hline \multirow[t]{2}{*}{ Enron (2005) } & Business ethics & $\operatorname{Cox}(2009)$ \\
\hline & "Ethics versus economics" & Macy and Terry (2008) \\
\hline Grumpier Old Man (1995) & Ethical dilemmas & Champoux (2006) \\
\hline Gung Ho (1986) & Cultural issues & Mallinger and Rossy (2003) \\
\hline Philadelphia (1993) & $\begin{array}{l}\text { Discrimination, ethical dilemmas created } \\
\text { by HIV Status at the workplace }\end{array}$ & Gonzales and Zarzosa (2008) \\
\hline Scent of a Woman (1992) & Ethical dilemmas & Champoux (2006) \\
\hline Shark Tale (2004) & Ethical dilemmas & Champoux (2006) \\
\hline Slumdog Millionaire (2008) & $\begin{array}{l}\text { Discussion of issues related to } \\
\text { stereotyping and prejudice }\end{array}$ & Cardon (2010) \\
\hline The Associate (1986) & New ventures & Bumpus (2005) \\
\hline The Breakfast Club (1985) & $\begin{array}{l}\text { Discussion of issues related to } \\
\text { stereotyping and prejudice }\end{array}$ & Christopher, et.al. (2004) \\
\hline The Corporation (2005) & $\begin{array}{l}\text { Business ethics, corporate social } \\
\text { responsibilities, ethical dilemmas }\end{array}$ & Hatfield (2008) \\
\hline The Emperor's Club (2002) & Ethical dilemmas & Champoux (2006) \\
\hline The Joy Luck Club (1993) & Motivation and personality subjects & Bumpus (2005) \\
\hline The Lion King (1994) & Leadership and role conflict & Comer (2001) \\
\hline The Magnificent Seven (1960) & Power, motivation, and influence tactics & Huczynski (1994) \\
\hline The Rising Sun (1993) & $\begin{array}{l}\text { Cross cultural communication and } \\
\text { transplant organizations }\end{array}$ & Foreman and Thatchenkery (1996) \\
\hline The Smoke Signals (1998) & Communication and perception & Bumpus (2005) \\
\hline Thirteen Days (2000) & $\begin{array}{l}\text { Complex and politicized decision } \\
\text { processes }\end{array}$ & Buchanan and Huczynski (2004) \\
\hline
\end{tabular}

Students also see the implementation of the concepts in various contextual settings with films. It is noted that using films as an effective pedagogical tool raises the interest of students without sacrificing academic rigor, 
allows classes to observe and evaluate processes in action, exposes students to a world beyond their own, and offers opportunities for discussion, values clarification and personal assessment (Berger \& Pratt, 1998).

Previous research suggests a framework to resolve and analyze the movies or to "connect things up". This framework can be either to the relevant management concept or to the discussion topic in the textbook (Dunphy, 2009). The use of the documentary film The Corporation in the classroom has also been discussed. Hatfield (2008) has argued the use of this film and stated that it is a powerful exemplification of ethical issues facing the financial manager in classroom settings. She argues that the documentaries can be used as a platform for live discussions for issues that could potentially occur, but her hypotheses were left untested.

\subsubsection{The Behavioral Paradox: Ethical Decision-Making and Management Behavior}

Ethical issues in business emerge because of isolation from traditional business decision-making. The scandals like Enron or WorldCom that large corporations face today did not occur independently of the companies' economic activities but were actualized according to a series of decisions that were made at various points in time and from those earlier decisions.

\section{Ethical Decision-Making}

Decision-making is one of main activities of management. It usually requires, respectively, to define and examine the problem, recognize the possible solutions, evaluate them, choose the best one, and then apply it. There are some critical points about the structure and feature of ethical decision-making (Carroll \& Buchholtz, 2000). Most ethical decisions have:

- Prolonged Consequences: Primary effects are pursued by a set of other consequences which are influential in organization.

- Multiple Alternatives: They do not have one best solution. Each solution can present in a different way of figuring out the problem.

- Mixed Results: Results are composite and sometimes confused. They have the lack of clarity.

- Undeterminable Consequences: Some results of a decision may be unexpected. This also brings about uncertainty.

- Individual Implications: Ethical problems can be personal and have personal advantage and disadvantages for the decision-makers.

Decision-making is a big responsibility for managers. Managers face ethical dilemmas in work place and try to make several decisions by considering their results in every aspect. Managers take into account the ethical values while making decisions since their ethical/unethical decisions affect the organizations as a whole. All stakeholders including employees, shareholders, suppliers, customers and public are affected by managers as decision-makers. Companies should prepare a series of values that are applied during decision making process. These values should highlight which actions are right or wrong for the organization (Bansal \& Kandola, 2004). Establishing a connection between ethical theory and management behavior could provide understanding of ethical manners. Therefore this understanding have raised the ethical awareness of them and shed light on seeing results of their decisions. Devastating outcomes of unethical behaviors of managers have resulted in the coming up of ethics itself and ethical issues (Premeaux, 2004).

The main ethical theories are built on three moral theories. Utilitarian theories suggest that people should judge their behavior by considering social outcomes. Theories of rights underline the rights people belong. Theories of justice center on multiple effects of decisions and procedures (Velasquez, 2006). These theories draw attention to different aspects of morality for individuals and take them from distinctive perspective. Howe ver, researchers do not have to follow one of these theories. They just provide the decision-making guideline for managers and will be useful and influential on their ultimate decisions (Premeaux, 2009).

\section{Social Responsibility in the Decision Making-Process}

Managers also have to take into account several values in the decision-making process. These values may affect the efficiency of decisions by the managers. Within this context, these values are called "managerial values". They include not only basic personal values but also acquired values from their roles in formal organizations. These are classified as economic, technological, political, environmental, aesthetical and social values. The importance of these values varies according to the process the managers try to carry out. Each process, profit maximization management, trusteeship management and life-quality management, requires distinct values to be considered. When the managers come to the level of life-quality management, it is required that they analyze external and internal environment of the corporation as a whole (Hodgetts \& Kuratko, 1991). Therefore, the term 
"social responsibility" has begun to become important.

Social responsibility is a responsibility for managers to take into account the outcomes of their decisions on all dynamics of social system. They take over social responsibility by looking after others who may be affected by organization actions. While deciding on something, managers think about their organization's goals (Carroll \& Buchholtz, 2000) and try to make them reasonable in terms of social responsibility. Corporate social responsibility (CSR) is defined as "meeting the needs or expectations of all stakeholders" (Bansal \& Kandola, 2004). Decisions of managers affect all stakeholders' activities in the long-term. It is assumed that decisions considering ethical values cannot lead to negative effects on the society. Undoubtedly, sometimes companies may lose their rational behavior to meet public needs and break laws to make more money.

From the perspective of complexity theory, it is possible to develop an understanding of how decision-makers behave in a complicated system. Rather rejecting the existence of contradictory or paradoxical driving forces within a company, a model asserted by complexity theory accepts that different shapes of normative orientation are at play within all of the system's complex dynamics. It makes it unrealizable to sort out a variety of values that flow within a complex system as being either "business" priorities or "ethical" considerations. Complexity theory seems to propose that business discretion and individuals' sense of normative propriety may not be of a distinctly different order at all (Morland, 2008). However, the main problem is the lack of information or utilitarian approach of managers. There occurs a paradox between realized and expected business concerns, decisions and management behavior. It may be useful, helpful and effective to benefit from supplementary educational tools including case studies, video clips and documentary/feature films to be comprehended this conflict (dilemma) and CSR concept to students better. The students, as the future business leaders, need to know and analyze the impact of their decisions on organizations, stakeholders and environment. Advantages of using films are visuality involvement and providing an opportunity to assess some cases with results. In this context, with regard to difficult-to-teach concepts of business ethics, some instructors have adopted to develop different educational techniques and materials.

\subsubsection{Teaching Business Ethics with Films}

To teach business ethics, and to do this in an understandable and true way is one of challenge facing by the lecturers. An average business ethics education aims to teach students about what are the basis of ethical theories and how students behave and decide ethically in workplace. Objectives varies from one course to another. Here are some examples of course objectives: to create an ethical awareness, to promote ethical behaviors, to provide an understanding of ethical reasoning, and to combine all objectives (Cox, Friedman and Edwards, 2009).

Business Ethics courses include abstract and abstruse concepts for students. Students need to be informed of possible ethical dilemmas that they will face in the business life. They want to advance their skills that let them to evaluate how ethical business decisions are in terms of all relationships and dynamics of the company (Hatfield, 2008). And this is a challenge for educators, they need to link between theory and practice, in order to prepare students for the ethical conflicts they will face in their future careers (Asaad, 2016).

Integrating films into a business ethics course as a presentation of ethical dilemmas, brings a catchy aspect to teaching, learning and understanding the ethical concepts. In this concern; because movies are presented in a narrative form, especially the documentary-style films, complex concepts can be understood better (Asaad, 2016). At this point the documentary, "The Corporation" can be utilized as a worthful practice-oriented teaching tool to present students a set of examples of ethical issues from real business life, to try to frame business ethics in a practical sense, and to associate theory and practice.

\section{Method}

In this study, the documentary film The Corporation is used as a teaching aid but not as a primary medium in an elective "Business Ethics and Corporate Social Responsibility" course. The Corporation is a documentary film based on interviews with corporate insiders, carefully composed resulting in a documentary that provides a challenging view of corporations' responsibilities to society in general. There are no actors in the film, which causes the character dramatizations to be minimal.

The Corporation does provide some interesting anecdotes in which corporations have behaved ill. The main question considered in The Corporation is "if corporations are considered to be a person, what kind of a person are they?" The answer comes early in the film: a psychopath. Without considering the accompanying positive aspects and benefits, presenting the negative sides of business is a standard tool of the film. By using many different ideas from experts, business thinkers to corporate people, the film concludes that the corporation is today's dominant power, it is a greedy, amoral entity based on making as much profit as possible without caring 
about ethical, social and environmental responsibilities.

We hypothesize that viewing of the documentary "The Corporation" as a supplemental teaching material will attract students and create more awareness than traditional lecturing methods. This will in turn affect a change in understanding the ethical and social problems created by the corporations in the society. Thus, our hypothesis is that using of the documentary "The Corporation" in a Business Ethics and Corporate Social Responsibility course will create a relatively higher level of understanding on students watching the film, than that of the other group, for ethical dilemmas caused by behavioral paradox of corporations.

\section{$H_{0}$ : The viewing of the documentary "The Corporation" will not create a significant difference between two groups on their understanding levels. \\ $H_{1}$ : The viewing of the documentary "The Corporation" will create a significant difference between two groups on their understanding levels.}

For the purpose of the study, forty business administration undergraduate students from a public university in Istanbul, who attended a seventh semester undergraduate level course entitled "Business Ethics and Corporate Social Responsibility", were chosen to participate in the study. We prefer to study on $3{ }^{\text {rd }}$ year students since they took basic business administration courses such as Introduction to Business, Management and Organization, and Organizational Behavior. The sample is equally divided between genders. The age of the sample ranges from 20 to 25 . The average age is 21 .

Students attended the class given by the professor for 12 weeks. They were randomly divided into two groups at the end of the 12th week. The control group was consisting of 20 students and experimental group was 20 students. The control group received no extra material about the course, while the experimental group viewed The Corporation documentary. Then, both groups were asked to write an essay (of at least 300 words) considering the role and responsibilities of the corporations in the society at a 40- minute session in the classroom. Each essay was graded blindly by a teaching assistant over 100 (Table 2).

\section{Results}

According to gathered data from 40 students, results are shown Table 3-4-5.

Table 2. Group Statistics

\begin{tabular}{lrrrr}
\hline Group & N & \multicolumn{1}{c}{ Mean } & \multicolumn{1}{c}{ Std. Deviation } & \multicolumn{1}{l}{ Std. Error Mean } \\
\hline Control Group & 20 & 43,3333 & 33,36665 & 7,28120 \\
Experimental Group & 20 & 76,3158 & 17,06541 & 3,91507 \\
\hline
\end{tabular}

Upon grading the essays, the grades were analyzed statistically by using SPSS 17.0. Compared to the control group, students in the experimental group reported results that were highly significantly different $(\mathrm{p} \leq .01$ or lower). The results of independent samples t-tests were outlined in Table 3 through Table 5.

To test the null hypothesis, t-test for independent samples was used (Table 3). Before implementing the test, the normality assumption is checked. Two non-parametric tests (Mann-Whitney U test and Kolmogorov-Smirnov test) were also used to test the same null hypothesis (Table 4 and 5).

Table 3. Independent Samples Test

\begin{tabular}{|c|c|c|c|c|c|c|c|c|c|}
\hline & & & \multicolumn{7}{|c|}{ t-test for Equality of Means } \\
\hline & \multicolumn{4}{|c|}{$\begin{array}{l}\text { Levene's Test for } \\
\text { Equality of Variances }\end{array}$} & \multirow[b]{2}{*}{$\begin{array}{c}\text { Sig. } \\
\text { (2-tailed) }\end{array}$} & \multirow[b]{2}{*}{$\begin{array}{c}\text { Mean } \\
\text { Difference }\end{array}$} & \multirow[b]{2}{*}{$\begin{array}{l}\text { Std. Error } \\
\text { Difference }\end{array}$} & \multicolumn{2}{|c|}{$\begin{array}{l}95 \% \text { Confidence Interval of } \\
\text { the Difference }\end{array}$} \\
\hline & $\mathrm{F}$ & Sig. & $\mathrm{t}$ & df & & & & Lower & Upper \\
\hline $\begin{array}{l}\text { Equal variances } \\
\text { assumed }\end{array}$ & 11,156 &, 002 & $-3,872$ & 38 & ,000 & $-32,98246$ & 8,51898 & $-50,22822$ & $-15,73669$ \\
\hline $\begin{array}{l}\text { Equal variances } \\
\text { not assumed }\end{array}$ & & & $-3,990$ & 30,412 &, 000 & $-32,98246$ & 8,26702 & $-49,85639$ & $-16,10853$ \\
\hline
\end{tabular}

Both the parametric test (see Table 3) and the two non-parametric tests (see Table 4 and Table 5) show that there is highly significant evidence against the null hypothesis; that is, there is no difference between the means of the grades of the two groups. Therefore, we assume that the viewing of "The Corporation" documentary will create a significant awareness to the students' understanding of ethical and social issues. 
Table 4. Test Statistics ${ }^{\mathbf{b}}$

\begin{tabular}{lr}
\hline Mann-Whitneya U & 84,000 \\
\hline Wilcoxon W & 315,000 \\
Z & $-3,153$ \\
Asymp. Sig. (2-tailed) & $\mathbf{, 0 0 2}$ \\
Exact Sig. [2*(1-tailed Sig.)] & $\mathbf{, 0 0 1}^{\text {a }}$ \\
\hline
\end{tabular}

a. Not corrected for ties.

b. Grouping Variable: Group

Table 5. Test Statistics ${ }^{\mathrm{a}}$

\begin{tabular}{llr}
\hline & Absolute &, 514 \\
Most Extreme Differences & Positive &, 514 \\
& Negative &, 000 \\
\hline Kolmogorov-Smirnov Z & & 1,623 \\
Asymp. Sig. (2-tailed) & & $\mathbf{, 0 1 0}$ \\
\hline
\end{tabular}

a. Grouping Variable: Group

As a result, our analysis proved that using the documentary "The Corporation" as a supplementary tool in a Business Ethics and Corporate Social Responsibility course, raises the awareness of students about the role that corporations play in ethical, social, and environmental issues.

Before making a conclusion, it is important to consider the following limitations of this study:

- This documentary is a copyrighted material. Therefore, supplying a legal copy of the film might also bring some extra costs to be considered.

- No structured questionnaire were used to collect data, instead data were collected from the grades students have collected from their written essays.

- The cultural dimension might also be considered as a limit because of the content of the film was based on mainly the economical issues of USA, including corporations, regulations, ethical beliefs, and social structure.

\section{Discussion}

Due to the nature of the field of business ethics and corporate social responsibility, relevant course concepts and theories can be illustrated in a wide array of films and documentaries. This work has suggested the use of a documentary as a tool to illustrate, elucidate and ultimately teach ethical and social responsibility issues in business. An exploratory research design was used to analyze the effects of using the documentary "the Corporation" on the awareness state of the students in terms of ethical, social and environmental issues which have critical role in the decision making process of business managers.

At this point, the main objective was to make an evaluation about how the students assess this paradox including conflicts and dilemmas between "what is right" and "how it is perceived" in the business world. In conclusion, the results of this study suggest that using "The Corporation" documentary in the classroom can have a significant impact on students' understanding of ethical and social problems created by the corporations in the society.

Although there were many studies highlighting the use of films in different class settings, only a few (Sumstine, 1918; Cox et al. 2009) include statistical analysis to support the presented ideas. At this regard, this study statistically proves that the viewing of "The Corporation" documentary creates a significant increase in the students' awareness state regarding ethical, social, and environmental issues.

"The Corporation" presents the negative aspects of business without regarding the positive effects and provides some anecdotes about the behavioral paradox of corporations. Thus, it is emphasized that the students (regarded as future business managers) need to understand and figure out the impact their business decisions have on the stakeholders by using this documentary in this study. As an implication for lecturers, it is advised to use this documentary on the later semesters. Also, this documentary is a powerful tool to assess the business education system. Using it as a pre and post assessment tool (eg. at the beginning of the first semester and at the end of last semester), it is also possible to measure the effectiveness of business education, whether the curriculum made any changes on students' perception regarding ethical problems caused by managerial actions. 
For the future research about using "The Corporation" in business education, it might be convenient to consider the following statements:

- Using larger samples in similar studies might enable researchers to make a content analysis, which could bring the benefits of qualitative research.

- In this study, "The Corporation" was used as secondary material to supplement learning. It might be useful to test whether this documentary will create more benefit as a primary medium.

- The documentary is a relatively long one. It can be divided into segments, and can be shown and discussed separately supporting the course material for each week, thus comparing the reinforcement effect on the learning outcome.

With the rapid development of new technologies, our "wired world" is continually changing, and this requires educators to stay current with the latest educational technology. In addition; new generation is influenced more by what he/she sees, hears and does than what he/she reads and because films mimic real-life experience, students may learn better with films.

This study may play an instructive role for lecturers teaching Business Administration courses. Results of the study support that teaching with films makes students more interested in courses. Specific to Business Ethics Course, teachers may focus on how students find out ethical issues in a better way and exemplify these issues by using visual tools like films, videos, documentaries, animations and even games or simulations. With the rise of information era and new technologies, students need to catch and learn new business concepts via technology and this raises the importance of visual learning practices in the field of education. Not only for teachers, this study also stirs universities up to prepare a set of mixed education kit including readings, team assignments, case studies, games and films which are one of the most catchy materials for students.

\section{References}

Abbott, J., \& Achbar, M. (2005). The Corporation [Film]. (Available from Zeitgeist Films. ASIN: B0007DBJM8).

Ambrosini, V., Billsberry, J., \& Collier, N. (2008). Teaching Soft Issues in Strategic Management with Films: Arguments and Suggestions. International Journal of Management Education, 13(1), 63-72.

Asaad, C. T. (2016). Educational Entertainment: Integrating Business Ethics with Out-of-the Classroom Financial Documentaries. Journal of Financial Education, 42(1-2), 56-80.

Bansal, P., \& Kandola, S. (2004). Corporate Social Responsibility: Why Good People Behave Badly in Organizations. Ivey Business Journal, March/April, 2004, Reprint \#9B04TB10.

Berger, J., \& Pratt, C. B. (1998). Teaching Business-Communication Ethics with Controversial Films. Journal of Business Ethics, 17, 1817-1823. https://doi.org/10.1023/A:1005764931816

Buchanan, D., \& Huczynski, A. (2004). Images of Influence. Journal of Management Inquiry, 13(4), 312-323. https://doi.org/10.1177/1056492604270796

Bumpus, M. A. (2005). Using Motion Pictures to Teach Management: Refocusing the Camera Lens Through the Infusion Approach to Diversity. Journal of Management Education, 29(6), 792-815. https://doi.org/10.1177/1052562905277183

Butler, A. C., Zaromb, F. M., Lyle, K. B., \& Roediger, H. L. (2009). Using Popular Films to Enhance Classroom Learning: The Good, the Bad, and the Interesting. Psychological Science, 20(9), 1161-1168. https://doi.org/10.1111/j.1467-9280.2009.02410.x

Cardon, P. W. (2010). Using Films To Learn About The Nature of Cross-Cultural Stereotypes in Intercultural Business Communication Courses. Business Communication Quarterly, 73(2), 150-165. https://doi.org/10.1177/1080569910365724

Carroll, A. B., \& Buchholtz, A. K. (2000). Business and Society: Ethics and Stakeholder Management, $4^{\text {th }}$. Ed., South-Western Publishing.

Champoux, J. E. (1999). Film as a Teaching Resource. Journal of Management Inquiry, 8(2), 206-217. https://doi.org/10.1177/105649269982016

Champoux, J. E. (2004). Commentary on "Filmmaking and Research" and "Images of Influence". Journal of Management Inquiry, 13(4), 336-340. https://doi.org/10.1177/1056492604271034

Champoux, J. E. (2006). At the Cinema: Aspiring to a Higher Ethical Standard. Academy of Management 
Learning \& Education, 5(3), 386-390. https://doi.org/10.5465/AMLE.2006.22697031

Christopher, A. N., Walter, J. L., Marek, P., \& Koenig, C. S. (2004). Using a "New Classic" Film to Teach About Stereotyping and Prejudice. Teaching of Psychology, 31(3), 199-202.

Clawson, J. G. S. (2006). Enhancing the Conversation: Audiovisual Tools and Techniques, in: J.G.S. Clawson and M.E. Haskins (Eds.). Teaching Management: A Field Guide for Professors, Corporate Trainers, and Consultants. Cambridge: Cambridge University Press, 228-241.

https://doi.org/10.1017/cbo9780511617850.015

Comer, D. R. (2001). Not Just a Mickey Mouse Exercise: Using Disney's The Lion King to Teach Leadership. Journal of Management Education, 25(4), 430-436. https://doi.org/10.1177/105256290102500407

Cox, P. L., Friedman, B. A., \& Edwards, A. L. (2009). Enron: The Smartest Guys in the Room-Using the Enron Film to Examine Student Attitudes towards Business Ethics. Journal of Behavioral and Applied Management, 10(2), 263-290.

Dunphy, S. (2009). Management Goes to the Movies. Proceedings of ASBBS Annual Conference, Las Vegas, 16(1).

Dunphy, S., Meyer, D., \& Linton, S. (2008). The Top 10 Greatest Screen Legends and What Their Definitive Roles Demonstrate about Management and Organizational Behaviour. Behaviour \& Information Technology, 27(2), (March-April), 183-188. https://doi.org/10.1080/01449290600875177

Fee, A., \& Budde-Sung, A. E. K. (2014). Using Video Effectively in Diverse Classes: What Students Want. Journal of Management Education, 36(6), 843-874. https://doi.org/10.1177/1052562913519082

Fleig, W. J. (1950). The Use of Films in Accounting Instruction. Accounting Review, 25(1), 94-96.

Foreman, J., \& Thatchenkery, T. J. (1996). Filmic Representations for Organizational Analysis: The Characterization of a Transplant Organization in the Film Rising Sun. Journal of Organizational Change Management, 9(3), 44-61. https://doi.org/10.1108/09534819610116628

Frieden, J. A., \& Deborah, W. E. (2007). Teach with Movies: Using the Storytelling Power of Movies to Motivate Students. Teacher Librarian, 34(3), 61-62.

Gonzales, C. B., \& Zarzosa, A. F. (2008). The Film Philadelphia As A Case Study of Ethical Dilemmas in the Workplace. Journal of Business Case Studies, 4(7), 41-46. https://doi.org/10.19030/jbcs.v4i7.4794

Hansen, J. E. (1933). The Effect of Educational Motion Pictures upon the Retention on Informational Learning. Journal of Experimental Education, 2(1), 1-4. https://doi.org/10.1080/00220973.1933.11009923

Hatfield, P. (2008). Using 'The Corporation' As a Powerful Illustration of Ethical Issues Facing The Financial Manager. 2008 ABR \& TLC Conference Proceedings, Orlando, Florida, USA.

Higgins, J. A., \& Dermer, S. (2001). The Use of Film in Marriage and Family Counselor Education. Counselor Education\&Supervision, 40, 182-192. https://doi.org/10.1002/j.1556-6978.2001.tb01251.x

Hodgetts, R. M., \& Kuratko, D. F. (1991). Management. Third Ed., San Diego: HBJ.

Huczynski, A. (1994). Teaching Motivation and Influencing Strategies Using the Magnificent Seven. Journal of Management Education, 18(2), 273-278. https://doi.org/10.1177/105256299401800215

Huczynski, A., \& Buchanan, D. (2004). Theory from Fiction: A Narrative Process Perspective on the Pedagogical Use of Feature Film. Journal of Management Education, 28(6), 707-726. https://doi.org/10.1177/1052562903262163

Huczynski, A., \& Buchanan, D. (2006). Feature Films in Management Education: Beyond Illustration and Entertainment. Journal of Organizational Behavior Education, 1, 73-94.

Janpol, H. L., \& Dilts R.. (2016). Does Viewing Documentary Films Affect Environmental Perceptions and Behaviors? Applied Environmental Education \& Communication, 15(1), 90-98. https://doi.org/10.1080/1533015X.2016.1142197

Kester, G. W. (2008). Barbarians in the Classroom: The Case of RJR Nabisco. Proceedings of the Financial Education Association 2008 Annual Meeting, Journal of the Academy of Business Education, 9, 2008.

Kester, G. W., Cooper, G. J., Dean, R. A., Gianiodis, P. T., \& Goldsby, M. G. (2009). Hollywood Movies in the Classroom: Bringing Finance and Business Ethics Alive. Proceedings of the Financial Education Association 2009 Annual Meeting. Journal of the Academy of Business Education, 10, 2009. 
Macy, A., \& Terry, N. (2008). Using Movies as a Vehicle For Critical Thinking in Economics and Business. Journal of Economics and Economic Education Research, 9(1), 31-50.

Mallinger, M., \& Rossy, G. (2003). Films as a Lens For Teaching Culture: Balancing Concepts, Ambiguity, and Paradox. Journal of Management Education, 27(5), 608-624. https://doi.org/10.1177/1052562903252642

Morland, M. P. (2008). Business Ethics as Practice. Cambridge: Cambridge University Press. https://doi.org/10.1017/CBO9780511488641

O’Boyle, E. J., \& Sandona, L. (2014). Teaching Business Ethics Through Popular Feature Films: An Experiential Approach. Journal of Business Ethics, 121, 329-340. https://doi.org/10.1007/s10551-013-1724-0

Premeaux, S. R. (2004). The Current Link Between Management Behavior and Ethical Philosophy. Journal of Business Ethics, 51, 269-278. https://doi.org/10.1023/B:BUSI.0000032495.53772.42

Premeaux, S. R. (2009). The Link Between Management Behavior and Ethical Philosophy in the Wake of the Enron Convictions. Journal of Business Ethics, 85, 13-25. https://doi.org/10.1007/s10551-008-9745-9

Scherer, R. F., \& Baker, B. (1999). Exploring Social Institutions through the Films of Frederick Wiseman. Journal of Management Education, 23(2), 143-153. https://doi.org/10.1177/105256299902300204

Smith, G. W. (2009). Using Feature Films as the Primary Instructional Medium to Teach Organizational Behavior, Journal of Management Education, 33(4), 462-489. https://doi.org/10.1177/1052562909335861

Sumstine, D. R. (1918). A Comparative Study of Visual Instruction in the High School. School and Society, 7 , 235-238.

Tyler, C. L., Anderson, M. H., \& Tyler, J. M. (2009). Giving Students New Eyes: The Benefits of Having Students Find Media Clips to Illustrate Management Concepts. Journal of Management Education, 33(4), 444-461. https://doi.org/10.1177/1052562907310558

Velasquez, M. (2006). Business Ethics. Sixth Ed., Pearson Education, Upper Saddle River, NJ.

Villalba, J. A., \& Redmond, R. E. (2008). Crash: Using a Popular Film as an Experiential Learning Activity in a Multicultural Counseling Course. Counselor Education \& Supervision, 47, 264-276. https://doi.org/10.1002/j.1556-6978.2008.tb00056.x

Wegner, H. (1977). Teaching with Film. The Phi Delta Kappa Educational Foundation, Bloomington, Indiana, ISBN 0-87367-103-1.

\section{Copyrights}

Copyright for this article is retained by the author(s), with first publication rights granted to the journal.

This is an open-access article distributed under the terms and conditions of the Creative Commons Attribution license (http://creativecommons.org/licenses/by/4.0/). 